\title{
Capacity of Absorption and Removal of Heavy Metals from Scirpus californicus and Its Potential Use in the Remediation of Polluted Aquatic Environment
}

\author{
Walter Cuadrado, María Custodio*, Ciro Espinoza, Carmela Vicuña, Marilú Uribe \\ Universidad Nacional del Centro del Perú, Huancayo, Peru \\ Email: *mcustodio@uncp.edu.pe
}

How to cite this paper: Cuadrado, W., Custodio, M., Espinoza, C., Vicuña, C. and Uribe, M. (2019) Capacity of Absorption and Removal of Heavy Metals from Scirpus californicus and Its Potential Use in the Remediation of Polluted Aquatic Environment. Open Journal of Marine Science, 9, 74-85.

https://doi.org/10.4236/ojms.2019.92006

Received: February 1, 2019

Accepted: March 1, 2019

Published: March 4, 2019

Copyright $\odot 2019$ by author(s) and Scientific Research Publishing Inc. This work is licensed under the Creative Commons Attribution International License (CC BY 4.0).

http://creativecommons.org/licenses/by/4.0/

\begin{abstract}
The research aimed to evaluate the absorption and removal capacity of $\mathrm{Cu}$, $\mathrm{Pb}, \mathrm{Fe}$ and $\mathrm{Zn}$ from Scirpus californicus for potential use in the remediation of polluted aquatic environments. Initially, Scirpus californicus plants were conditioned in 1.5 liters of $10 \mathrm{ppm} \mathrm{Cu}$ solution at a $\mathrm{pH}$ of 2.3 as well as $\mathrm{Pb}, \mathrm{Fe}$ and $\mathrm{Zn}$. Subsequently, the concentration of heavy metals in the root-rhizome, submerged stem and aerial stem was determined; the solution and $\mathrm{pH}$ were also analyzed. The greatest capacity of absorption and accumulation occurred in the root-rhizome reaching values for $\mathrm{Cu}$ of $491.84, \mathrm{~Pb}$ of $739.43, \mathrm{Zn}$ of 830.71 and Fe of $2624.72 \mathrm{mg} / \mathrm{kg}$ dry followed by the submerged stem and low values for the aerial stem. The removal efficiency of $\mathrm{Cu}$ from the solution was $52.10 \%, \mathrm{~Pb} 53.50 \%, \mathrm{Fe} 48.00 \%$ and $\mathrm{Zn} 50.20 \%$. It is concluded that the contact time has a significant effect on the absorption and removal capacity of the metals under study.
\end{abstract}

\section{Keywords}

Phytoremediation, Absorption and Accumulation, Heavy Metals, Scirpus californicus

\section{Introduction}

Environmental pollution by heavy metals is one of the main problems of society in the $21^{\text {st }}$ century, as it affects not only the physical environment but also the functioning of ecosystems. Once released into the environment, heavy metals circulate between biotic and abiotic cycles, accumulate in different compartments of the food chain and can reach toxic concentrations for animals, plants, micro- 
organisms and even man [1]. Nowadays, heavy metals have a great significance as indicators of the ecological quality of any aquatic ecosystem due to their toxicity and especially to the bioaccumulative behavior they possess.

Water pollution by heavy metals is a major environmental problem in modern society. Pollutants enter aquatic ecosystems through the discharge of wastewater from industrial, urban and agricultural runoff. Compared to organic pollutants, natural decomposition processes do not remove heavy metals. In contrast, they can accumulate in aquatic biota and become organic complexes, which can potentially become more toxic [2] and cause irreversible damage to human health. The removal of toxic metals from wastewater is essential for the control of environmental pollution.

Today, there are a variety of technologies to reduce water pollution, but they are expensive. An interesting alternative approach is phytoremediation, in which plants are used to stabilize or even remove metals from water through mechanisms of phytoaccumulation, phytodegradation and phytostabilization [3].

Aquatic macrophytes are the predominant organisms in lake ecosystems, which in comparison with other plant species can absorb metals through their roots and rhizomes, as well as through their leaves [4]. However, the accumulation of metals by macrophytes is affected by concentrations of metals in water and sediments and the speciation of metals such as free ions and humic complexes [5]. The emerging aquatic macrophyte Scirpus californicus, known as totora, is one of the most common plants living in the high Andean wetlands, able to withstand extreme environmental conditions, including the presence of toxic pollutants. The objective of this study was to evaluate the absorption and removal capacity of $\mathrm{Cu}, \mathrm{Pb}, \mathrm{Fe}$ and $\mathrm{Zn}$ of Scirpus californicus for its potential use in the remediation of polluted aquatic environments.

\section{Material and Methods}

\subsection{Breeding of Plants of Scirpus californicus}

S. californicus plants were collected from the community of Pomachaca-Tarma, in the Junín region, forming 64 experimental units; they were transferred in 10 liter capacity containers with water from their medium (Figure 1). Each of the experimental units consisted of 4 plants placed in 1.5 liters of distilled water. Of the total number of experimental units, 16 were placed in solutions of copper,
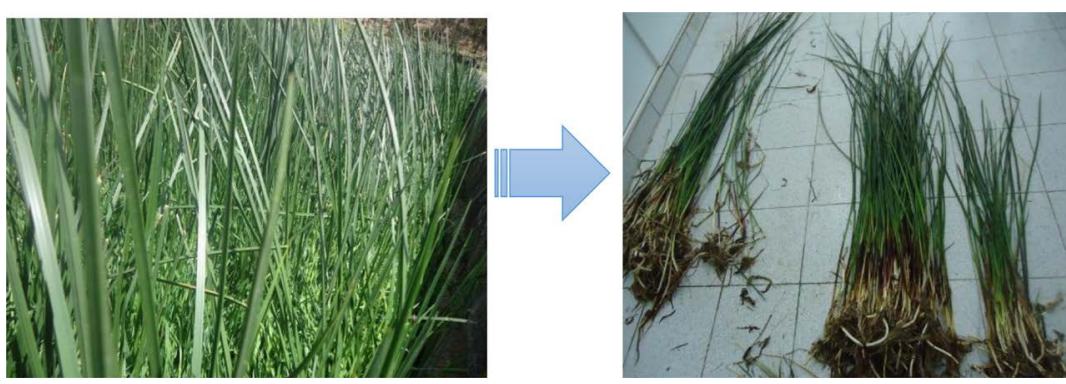

Figure 1. Selection of plants Scirpus californicus. 
lead, zinc and iron at a concentration of $10 \mathrm{ppm}$. Then, from each experimental unit and after contact times in each metal $\left(\theta_{1}, \theta_{2}, \theta_{3}, \theta_{4}, \theta_{5}, \theta_{6}, \theta_{7}\right.$ and $\left.\theta_{8}\right)$, the plants were extracted and divided into root-rhizome, aerial stem and submerged stem. Each of the parts was washed with drinking water and finally with distilled water and then proceeded to its analysis. We also collected $500 \mathrm{ml}$ of the solutions from the experimental units for the $\mathrm{pH}$ and concentration analyses of $\mathrm{Cu}$, $\mathrm{Pb}, \mathrm{Fe}$ and $\mathrm{Zn}$.

\subsection{Equipment and Reagents}

The equipment used was from the Laboratory of Analytical and Environmental Chemistry of the Faculty of Applied Sciences of the National University of the Center, such as: atomic absorption spectrophotometer Varian AA240, stove-Memmert, analytical balance OHAUS, iron, water distiller, $\mathrm{pH}$ meter HANNA instruments $\mathrm{HI}$ 3220. Merck branded chemically pure reagents were used such as copper nitrate $\left[\mathrm{Cu}\left(\mathrm{NO}_{3}\right)_{2}\right]$, lead nitrate $\left[\mathrm{Pb}\left(\mathrm{NO}_{3}\right)_{2}\right]$, zinc nitrate $\left[\mathrm{Zn}\left(\mathrm{NO}_{3}\right)_{2}\right]$, iron nitrate $\left[\mathrm{Fe}\left(\mathrm{NO}_{3}\right)_{3}\right]$, nitric acid $\left[\mathrm{HNO}_{3}\right]$, hydrochloric acid $[\mathrm{HCl}]$, perchloric acid $\left[\mathrm{HClO}_{4}\right]$, distilled water, $1000 \mathrm{ppm}$ standards of $\mathrm{Cu}, \mathrm{Pb}, \mathrm{Fe}$ and $\mathrm{Zn}$.

\subsection{Analysis of Samples}

This experiment was conducted to evaluate the ability of $S$. californicus to remove $\mathrm{Cu}, \mathrm{Pb}, \mathrm{Fe}$ and $\mathrm{Zn}$ from a synthetic water sample by exposure to different concentrations and contact times (Figure 2). Samples of each contact time were analyzed for metal concentration and $\mathrm{pH}$ according to standard methods [6].

a. Extraction: $S$. californicus was extracted from the community of Pomachaca-Tarma, taking care that its roots-rhizomes, aerial stem and submerged stem are not mistreated.

b. Selection: The selection of the plant went through a visual inspection, taking into account that the plant has the size and good physical and mature condition of the plant.

c. Washing 1: This washing allowed the elimination of impurities that accompany the plant such as soil, stones, etc., until the water is clear and free of solids.

d. Washing 2: The second washing was done with distilled water to eliminate impurities that can precipitate metals $(\mathrm{Cu}, \mathrm{Pb}, \mathrm{Fe}$ and $\mathrm{Zn})$.

e. Conditioning: The plants were conditioned in plastic containers with $1.5 \mathrm{~L}$ of solution of $10 \mathrm{ppm}$ of copper, lead, zinc and iron, individually and $2.30 \mathrm{pH}$. Sixteen experimental units were then prepared for each test.

f. Sampling: Sampling was conducted in duplicate for each proposed contact time. The samples were divided into parts; aerial stem, submerged stem and root-rhizome, then washed four times with potable water and twice with distilled water to remove impurities from the plant surface, the solution is completed at $1.5 \mathrm{~L}$ with distilled water, homogenized and sampled for metal concentration and $\mathrm{pH}$ analysis. 


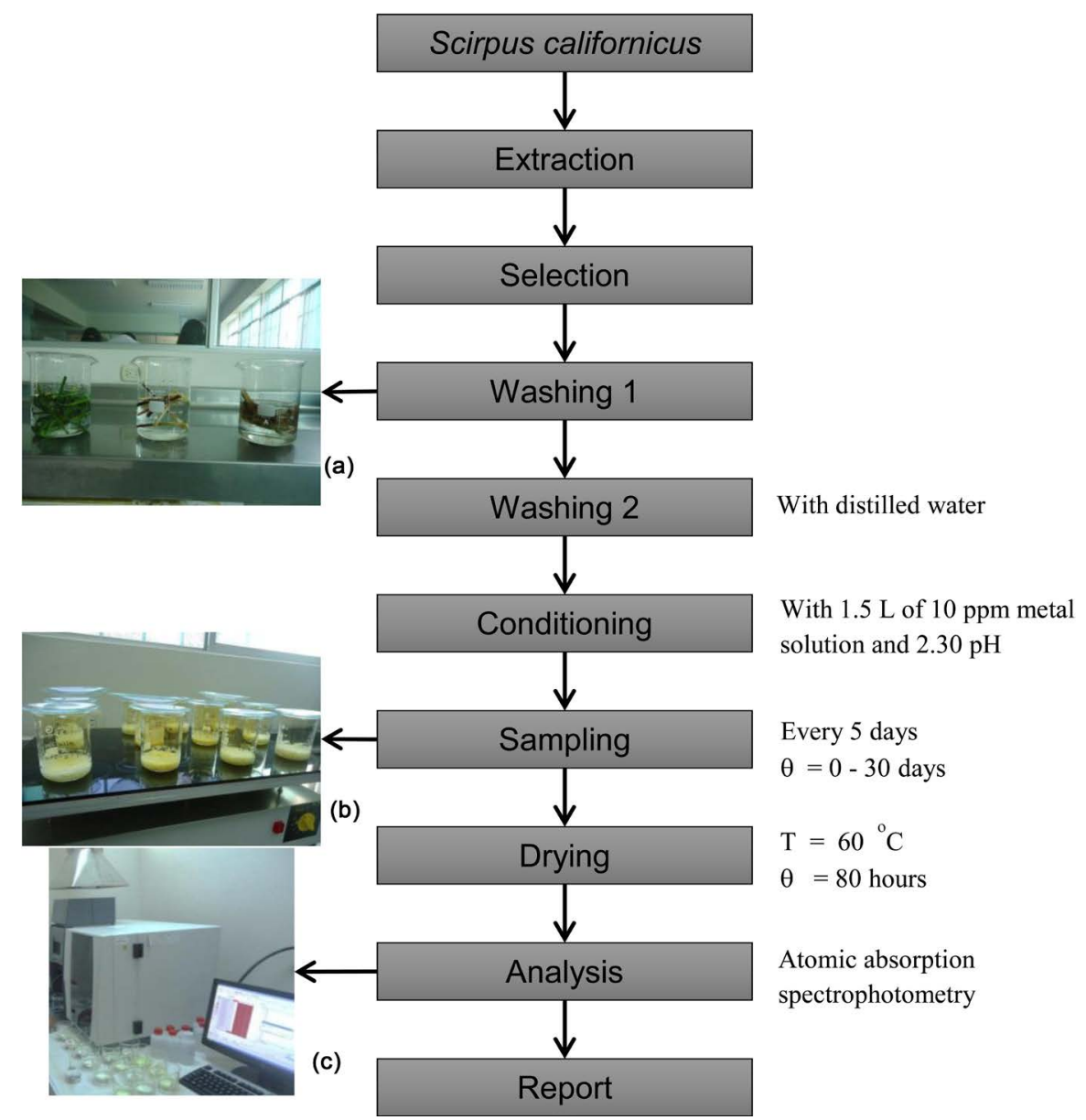

Figure 2. Flowchart to evaluate the Scirpus californicus plant. (a) Elimination of impurities, (b) digestion of the sample, (c) Analysis by atomic absorption.

g. Drying: Samples washed with distilled water were conditioned in meshes and dried at $60^{\circ} \mathrm{C}$ for 80 hours.

h. Analysis: Analyses were performed using the standardised method by atomic absorption.

i. Report: For plant parts in $\mathrm{mg} / \mathrm{kg}$ dry and for solution in $\mathrm{mg} / \mathrm{L}$ (ppm).

\subsection{Research Design}

S. californicus plants (aerial stem, submerged stem and root-rhizome) were evaluated with concentration solutions of $10 \mathrm{ppm} \mathrm{Cu}, 10 \mathrm{ppm} \mathrm{Pb}, 10 \mathrm{ppm} \mathrm{Zn}$ and $10 \mathrm{ppm} \mathrm{Fe}$, independently and contact times $\left(\theta_{1}, \theta_{2}, \theta_{3}, \theta_{4}, \theta_{5}, \theta_{6}\right.$ and $\left.\theta_{8}\right)$. The design was applied completely at random, in order to adequately control the variables as detailed in Table 1 .

The removal of copper, lead, zinc or iron was determined by applying the material balance formula:

$$
\text { \%Removal }=\left(\frac{Y_{i}-Y_{f}}{Y_{i}}\right) \times 100
$$

where: 
Table 1. Experimental design to be developed in research.

\begin{tabular}{ccccccc}
\hline & \multicolumn{5}{c}{ Scirpus californicus } \\
\cline { 2 - 7 } Evaluation days & \multicolumn{2}{c}{ Aerial stem } & \multicolumn{2}{c}{ Submerged stem } & \multicolumn{2}{c}{ Root-Rhizome } \\
\cline { 2 - 7 } & $\mathrm{R}_{1}$ & $\mathrm{R}_{2}$ & $\mathrm{R}_{1}$ & $\mathrm{R}_{2}$ & $\mathrm{R}_{1}$ & $\mathrm{R}_{2}$ \\
\hline$\theta_{1}$ & $\mathrm{~A}_{11}$ & $\mathrm{~A}_{21}$ & $\mathrm{~A}_{11}$ & $\mathrm{~A}_{21}$ & $\mathrm{~A}_{11}$ & $\mathrm{~A}_{21}$ \\
$\theta_{2}$ & $\mathrm{~A}_{12}$ & $\mathrm{~A}_{22}$ & $\mathrm{~A}_{12}$ & $\mathrm{~A}_{22}$ & $\mathrm{~A}_{12}$ & $\mathrm{~A}_{22}$ \\
$\theta_{3}$ & $\mathrm{~A}_{13}$ & $\mathrm{~A}_{23}$ & $\mathrm{~A}_{13}$ & $\mathrm{~A}_{23}$ & $\mathrm{~A}_{13}$ & $\mathrm{~A}_{23}$ \\
$\theta_{4}$ & $\mathrm{~A}_{14}$ & $\mathrm{~A}_{24}$ & $\mathrm{~A}_{14}$ & $\mathrm{~A}_{24}$ & $\mathrm{~A}_{14}$ & $\mathrm{~A}_{24}$ \\
$\theta_{5}$ & $\mathrm{~A}_{15}$ & $\mathrm{~A}_{25}$ & $\mathrm{~A}_{15}$ & $\mathrm{~A}_{25}$ & $\mathrm{~A}_{15}$ & $\mathrm{~A}_{25}$ \\
$\theta_{6}$ & $\mathrm{~A}_{16}$ & $\mathrm{~A}_{26}$ & $\mathrm{~A}_{16}$ & $\mathrm{~A}_{26}$ & $\mathrm{~A}_{16}$ & $\mathrm{~A}_{26}$ \\
$\theta_{7}$ & $\mathrm{~A}_{17}$ & $\mathrm{~A}_{27}$ & $\mathrm{~A}_{17}$ & $\mathrm{~A}_{27}$ & $\mathrm{~A}_{17}$ & $\mathrm{~A}_{27}$ \\
$\theta_{8}$ & $\mathrm{~A}_{18}$ & $\mathrm{~A}_{28}$ & $\mathrm{~A}_{18}$ & $\mathrm{~A}_{28}$ & $\mathrm{~A}_{18}$ & $\mathrm{~A}_{28}$ \\
\hline
\end{tabular}

$\mathrm{A}_{11} \ldots \mathrm{A}_{28}=$ Concentrations of copper, lead, zinc and iron individually in the Scirpus californicus plant (aerial stem, submerged stem and root-rhizome), in solution and $\mathrm{pH} . \theta_{1}, \theta_{2}, \theta_{3}, \theta_{4}, \theta_{5}, \theta_{6}, \theta_{7}$ and $\theta_{8}=$ Contact times a $0,2,5,10,15,20,25$ and 30 days.

$Y_{i}=$ Initial metal concentration $(\mathrm{Cu}, \mathrm{Pb}, \mathrm{Fe}$ and $\mathrm{Zn})$.

$Y_{f}=$ Final metal concentration.

\subsection{Data Analysis}

In order to evaluate the native $S$. californicus plant in the removal of copper, lead, zinc and iron, data were organized and the design was used entirely at random. When the difference between the treatments was found, the Tukey [7] mean comparison test was used at a significance level of 0.05 with the following linear additive model:

$$
Y_{i j}=\mu+\Gamma_{i}+\mathcal{E}_{i j}, \quad i=1,2,3, \cdots, t ; j=1,2,3, \cdots, b
$$

where:

$i$ : level of the factor parts of $S$. californicus.

$b$ : level of the factor days of evaluation of the removal and/or absorption of metals.

$Y_{i j}$ : value observed on the $j$-th day of evaluation of metal removal and/or absorption for the ith parts of the native plant Scirpus californicus.

$\mu:$ is the overall mean, estimated by the mean of the experiment: $\bar{x}$.

$\Gamma_{i}$ : measures the effect of treatment $i$, estimated by experiment.

$\mathcal{E}_{i j}$ : is the random error associated with the answer $Y_{i j}$

\section{Results and Discussion}

The $S$. californicus plant, like any living being, has the capacity to absorb or adsorb substances such as copper, lead, zinc and iron. However, many of them are beneficial for their subsistence, while others are detrimental to their physiological processes. In this investigation it is shown values found in the treatments and repetitions, which increase in direct relation to the amount of metals applied in 
each treatment to $S$. californicus.

Figure 3 shows the absorption of copper during the experimental period for $S$. californicus. The greatest absorption occurred in the root-rhizome, followed by the submerged stem that after 15 to 30 days remains constant and in smaller quantity in the aerial stem that from 2 to 30 days remains constant.

Initially, the removal rates of heavy metals in the experiments were relatively slow in the first two days; this is because plants need a certain amount of time to adapt to a new environment [8]. Figure 4 shows the results of the efficiency of removing copper from the solution at a given $\mathrm{pH}$. During the 30 days the removal was from $10.0 \mathrm{mg} / \mathrm{L}$ to $4.79 \mathrm{mg} / \mathrm{L}$. Similar results were observed for emerging species and free floating species [9]. A higher accumulation of metals in aquatic plant roots compared to leaf accumulation is a widely proven fact. However, in exposures of $S$. californicus samples to elevated metal concentrations a significant translocation to the aerial stem was observed. However, they did not exceed the concentrations determined in the root-rhizome system.

Figure 5 shows that the greatest absorption of lead occurred in the root-rhizome, followed by the submerged stem and in lesser quantity in the aerial stem, which remains constant for 10 to 30 days. In Figure 6, the results of the removal of lead from the solution at a determined $\mathrm{pH}$ are presented; which reveals that the removal during the 30 days varied from $10.0 \mathrm{mg} / \mathrm{L}$ to $4.65 \mathrm{mg} / \mathrm{L}$.

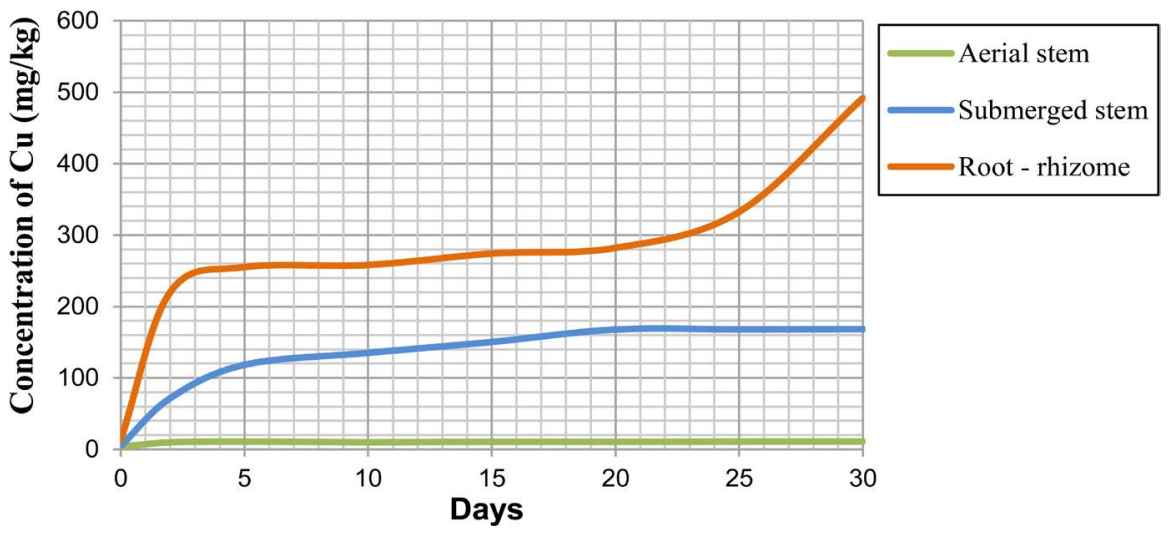

Figure 3. Copper absorption in the aerial stem, submerged stem and root-Scirpus californicus rhizome.

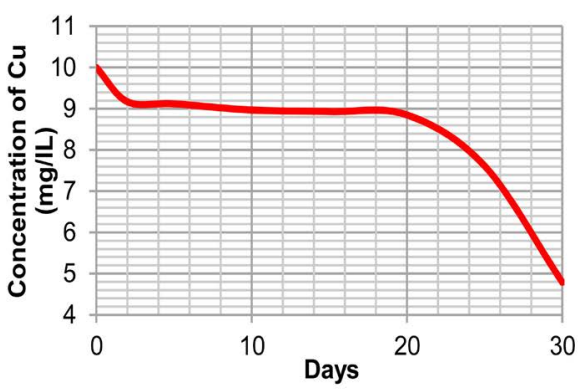

(a)

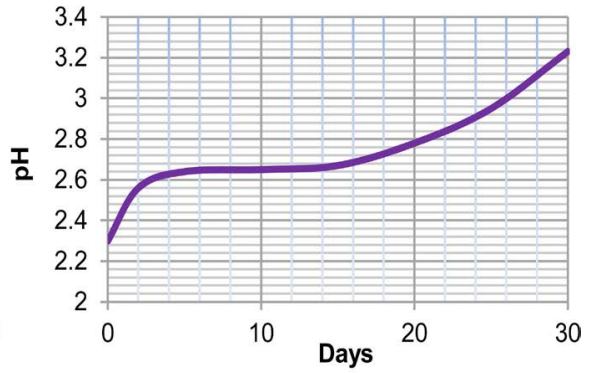

(b)

Figure 4. Concentration of $\mathrm{Cu}$ of the solution versus time (a). Behavior of $\mathrm{pH}$ versus time in copper solution (b). 


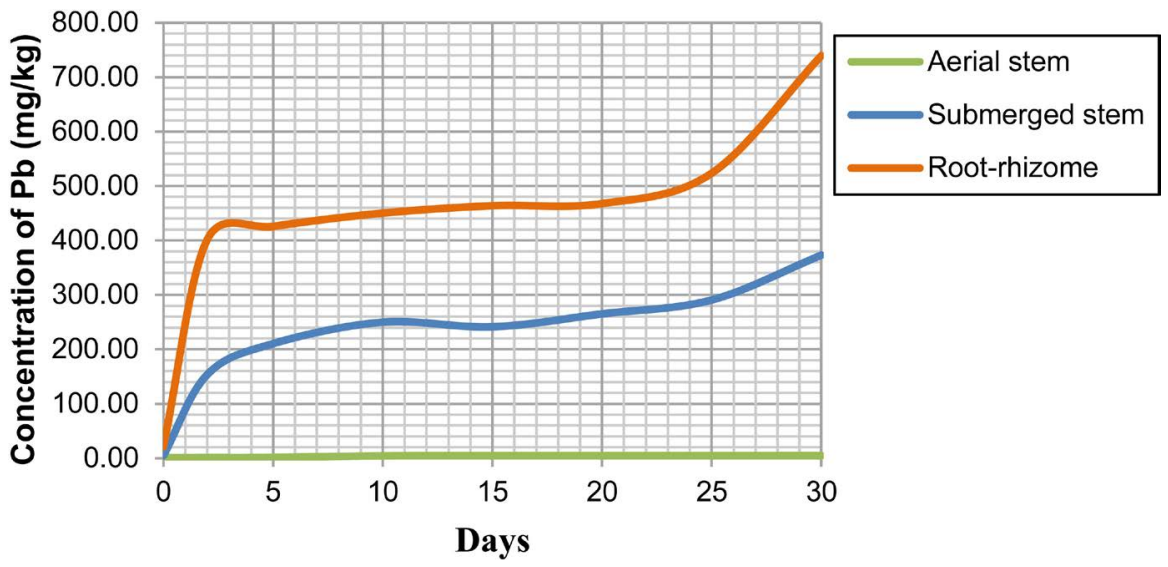

Figure 5. Absorption of lead in the aerial stem, submerged stem and root-rhizome of the plant Scirpus californicus.

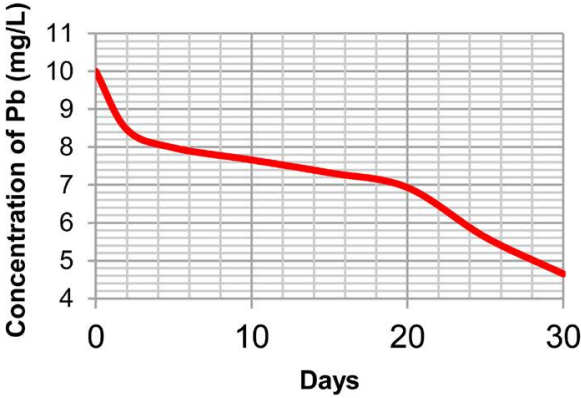

(a)

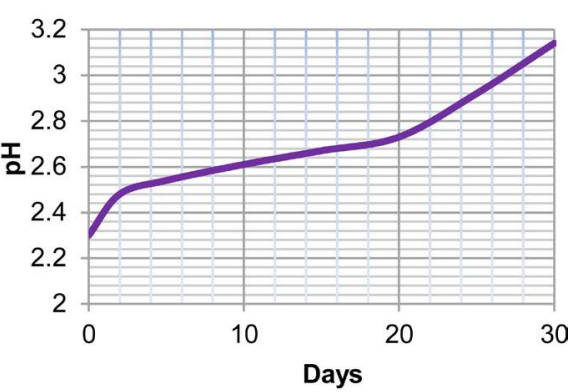

(b)

Figure 6. Concentration of lead in the solution versus time (a). Behaviour of $\mathrm{pH}$ versus time in lead solution (b).

Lead is the most toxic metal than other metals and immobile because of its strong bond to organic matter and other plant components [10] [11]. The results obtained are supported by Zevallos et al. [12], who refer that the accumulation of $\mathrm{Pb}^{2+}$ in plants is regulated by physicochemical parameters such as the $\mathrm{pH}$ of the medium, presence of exudates, the cation exchange capacity of its surface, etc. Vascular plants absorb and accumulate $\mathrm{Pb}^{2+}$ mainly in the roots and only a small part is translocated to the aerial part [13]. It is interesting to note that in similar work using other floating aquatic plants and under analogous experimental conditions, it is reported that most of the $\mathrm{Pb}^{2+}$ removed from an aqueous solution (57\% - 77.5\%) was left in the roots of Eicchornia crassipes when exposed to various concentrations in the range of $15-200 \mathrm{mg} \mathrm{Pb} / \mathrm{L}$ after 14 days. The retention of $\mathrm{Pb}^{2+}$ in the roots is due to its binding to certain cell wall molecules, ion exchange sites and extracellular precipitation, mainly in the form of carbonates.

The $S$. californicus plant showed the ability to tolerate significantly high concentrations of zinc. Figure 7 shows that the highest zinc absorption occurred after 20 days of contact at the root-rhizome, followed by the submerged stem which at 20 to 30 days remains constant and in lesser quantity at the aerial stem which at 15 to 30 days also remains constant. This result is due to the greater capacity of plants to absorb micronutrients compared to non-essential or toxic 
elements, for which plants can generate tolerance strategies [14]. A range of zinc concentrations between 0.070 and $0.40 \mathrm{mg} / \mathrm{g}$ could be considered toxic to plants, while the level of toxic zinc in plant tissue is $0.023 \mathrm{mg} / \mathrm{g}$ [14] [15]. In addition, several studies report that zinc binds to organic matter through electrostatic forces, indicating that a significant fraction of the metal bound to organic matter is determined in the interchangeable fraction [16].

In Figure 8, the results of the efficiency of zinc removal from the solution at a certain $\mathrm{pH}$ are shown, observing that during the 30 days the removal varied from $10.0 \mathrm{mg} / \mathrm{L}$ to $7.74 \mathrm{mg} / \mathrm{L}$.

In Figure 9, it is shown that iron absorption was greater in root-rhizome, that from 20 to 30 days remains constant, followed by the submerged stem that from 25 to 30 days remains constant and in lesser quantity in the aerial stem that from 5 to 30 days remains constant. Figure 10 shows the results of the efficiency of removing iron from the solution at a given $\mathrm{pH}$ during the 30 days, which ranged from $10.0 \mathrm{mg} / \mathrm{L}$ to $5.20 \mathrm{mg} / \mathrm{L}$. In all cases the tendency to the neutral aqueous medium is observed. Similar to that obtained by Serrano where initial $\mathrm{pH}$ was of 5 and increase to 6.5 .

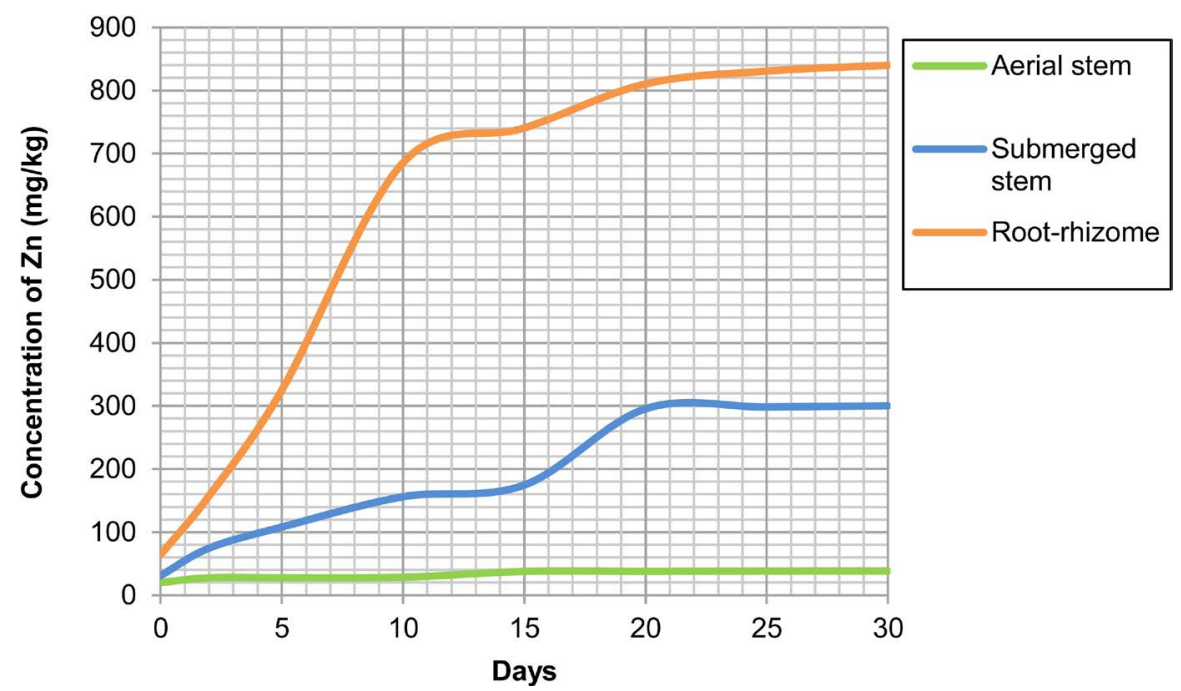

Figure 7. Absorption of zinc in the aerial stem, submerged stem and root-rhizome of the plant Scirpus californicus.

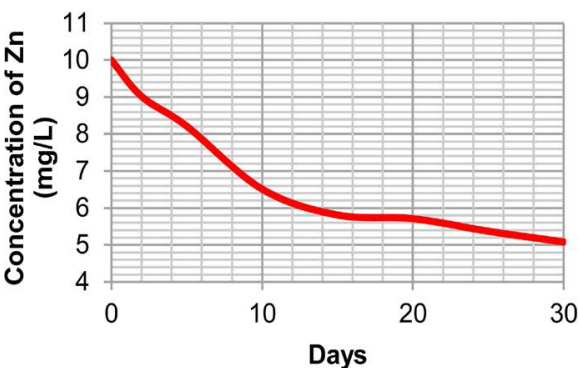

(a)

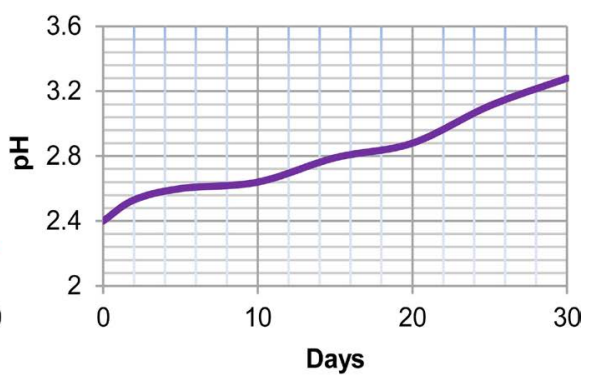

(b)

Figure 8. Concentration of Zinc in the solution versus time (a). Behaviour of $\mathrm{pH}$ versus time in zinc solution (b). 


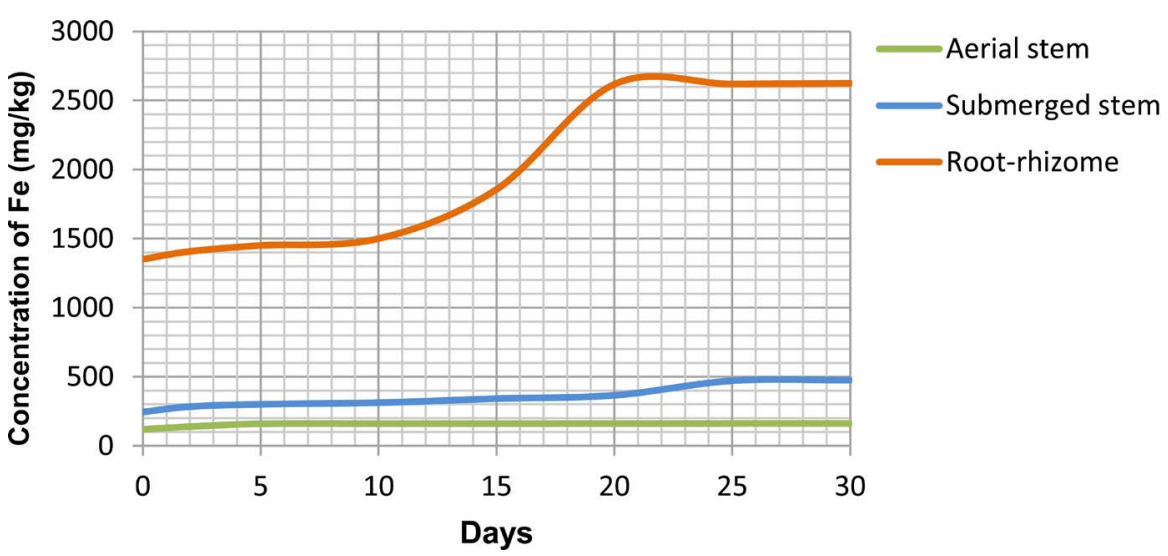

Figure 9. Absorption of iron in the aerial stem, submerged stem and root-rhizome of the plant Scirpus californicus against time.

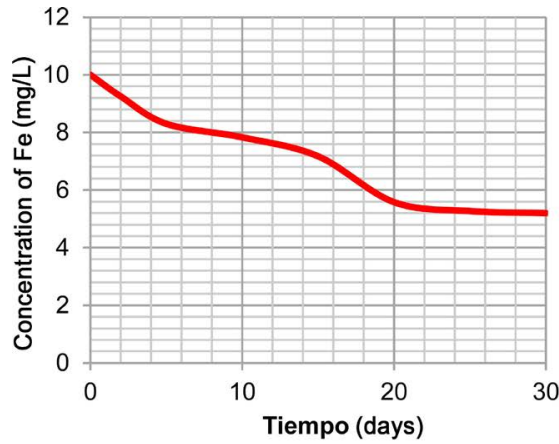

(a)

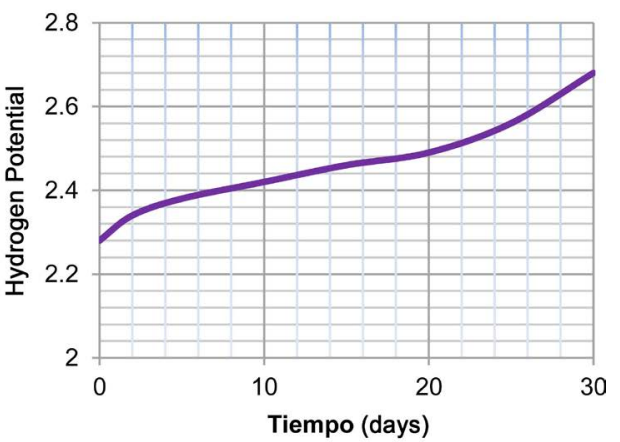

(b)

Figure 10. Concentration of iron in the solution versus time (a). Behaviour of the $\mathrm{pH}$ against time in the iron solution (b).

Similar studies support the results, stating that the root of Scirpus californicus accumulates lead, copper, chromium, nickel and arsenic [17]. In addition, the upward trend in accordance with the concentrations applied allows us to assume that the plant possibly has the capacity to tolerate concentrations greater than 2 ppm; therefore, we can infer that in new experiences we will find values higher than those found.

In general, the tolerance of plants to high concentrations of heavy metals is a function of various internal and external factors, such as phenology, vigour, growth, speciation of elements and water chemistry [18]. However, the compartmentalization of metals in the study made it possible to demonstrate the different patterns of mobility in the plant studied, considerations that must be taken into account in the remediation processes of polluted aquatic environments.

\section{Conclusions}

The native $S$. californicus plant showed an overall ability to significantly tolerate levels of copper, lead, zinc and iron. The absorption of copper by the root-rhizome of the native plant reached its maximum value at 30 days with $491.84 \mathrm{mg} / \mathrm{kg}$ dry, followed by the submerged stem that at 15 to 30 days remains constant with 
$168.45 \mathrm{mg} / \mathrm{kg}$ dry and to a lesser extent in the aerial stem that from 2 to 30 days remains constant with $11.01 \mathrm{mg} / \mathrm{kg}$ dry.

The greatest absorption of lead occurred after 30 days in the root-rhizome with $739.43 \mathrm{mg} / \mathrm{kg}$ dry, followed by the submerged stem which at 30 days was $373.01 \mathrm{mg} / \mathrm{kg}$ dry and in lesser quantity in the aerial stems which from 10 to 30 days remains constant with $4.71 \mathrm{mg} / \mathrm{kg}$ dry. Zinc absorption was higher in the root-rhizome with $830.71 \mathrm{mg} / \mathrm{kg}$ dry on average at 20 days, and then remains constant, followed by submerged stem with $295.45 \mathrm{mg} / \mathrm{kg}$ at 20 days and less in the aerial stem with $37.72 \mathrm{mg} / \mathrm{kg}$ dry at 15 days. The greatest absorption of iron occurred in the root-rhizome at 20 and 30 days remains constant with $2624.72 \mathrm{mg} / \mathrm{kg}$ dry, followed by the submerged stem that at 25 to 30 days remains constant with $475.07 \mathrm{mg} / \mathrm{kg}$ dry and less in the aerial stem that from 5 to 30 days remains constant with $162.12 \mathrm{mg} / \mathrm{kg}$ dry.

The efficiency of removing copper from the solution during the 30 days was $52.10 \%$, for lead $53.5 \%$, zinc $50.20 \%$ and iron $48.00 \%$. The behavior of the hydrogen potential of the individual tests of removal of copper, lead, zinc and iron was at the beginning of 2.30 on average, which indicates that the aqueous medium is acid during the 30 days evolved in ascending form until the order of 3 .

\section{Acknowledgements}

The authors express their gratitude to the Laboratory of Analytical and Environmental Chemistry of the Faculty of Applied Sciences of the Universidad Nacional del Centro del Peru for allowing us to make use of the equipment and materials for this study.

\section{Conflicts of Interest}

The authors declare no conflicts of interest regarding the publication of this paper.

\section{References}

[1] Mishra, V.K., Upadhyay, A.R., Pandey, S.K. and Tripathi, B.D. (2008) Concentrations of Heavy Metals and Aquatic Macrophytes of Govind Ballabh Pant Sagar an Anthropogenic Lake Affected by Coal Mining Effluent. Environmental Monitoring and Assessment, 141, 49-58. https://doi.org/10.1007/s10661-007-9877-x

[2] Mazej, Z. and Germ, M. (2009) Trace Element Accumulation and Distribution in Four Aquatic Macrophytes. Chemosphere, 74, 642-647.

https://doi.org/10.1016/j.chemosphere.2008.10.019

[3] Machado, A.I., Beretta, M., Fragoso, R. and Duarte, E. (2017) Overview of the State of the Art of Constructed Wetlands for Decentralized Wastewater Management in Brazil. Journal of Environmental Management, 187, 560-570. https://doi.org/10.1016/j.jenvman.2016.11.015

[4] Łojko, R., Polechońska, L., Klink, A. and Kosiba, P. (2015) Trace Metal Concentrations and Their Transfer from Sediment to Leaves of Four Common Aquatic Macrophytes. Environmental Science and Pollution Research, 22, 15123-15131. https://doi.org/10.1007/s11356-015-4641-1 
[5] Krämer, U. (2010) Metal Hyperaccumulation in Plants. Annual Review of Plant Biology, 61, 517-534.

http://www.annualreviews.org/doi/10.1146/annurev-arplant-042809-112156 https://doi.org/10.1146/annurev-arplant-042809-112156

[6] American Public Health Association, American Water Works Association and Water Pollution Control Federation (2012) Standard Methods for the Examination of Water and Wastewater. Standard Methods, 541.

[7] Sahu, P.K., Pal, S.R. and Das, A.K. (2015) Estimation and Inferential Statistics. Springer, India, 1-317. https://doi.org/10.1007/978-81-322-2514-0

[8] Lin, H., Liu, J.F., Dong, Y.B., Ren, K.Q. and Zhang, Y. (2018) Absorption Characteristics of Compound Heavy Metals Vanadium, Chromium, and Cadmium in Water by Emergent Macrophytes and Its Combinations. Environmental Science and Pollution Research, 25, 17820-17829. https://doi.org/10.1007/s11356-018-1785-9

[9] Hadad, H.R., Mufarrege, M.M., Pinciroli, M., Di Luca, G.A. and Maine, M.A. (2010) Morphological Response of Typha domingensis to an Industrial Effluent Containing Heavy Metals in a Constructed Wetland. Archives of Environmental Contamination and Toxicology, 58, 666-675. https://doi.org/10.1007/s00244-009-9454-0

[10] Aksoy, A., Duman, F. and Sezen, G. (2005) Heavy Metal Accumulation and Distribution in Narrow-Leaved Cattail (Typha angustifolia) and Common Reed (Phragmites australis). Journal of Freshwater Ecology, 20, 783-785. https://doi.org/10.1080/02705060.2005.9664806

[11] Kastratović, V., Krivokapić, S., Đurović, D. and Blagojević, N. (2013) Seasonal Changes in Metal Accumulation and Distribution in the Organs of Phragmites australis (Common Reed) from Lake Skadar, Montenegro. Journal of the Serbian Chemical Society, 78, 1241-1258. https://doi.org/10.2298/JSC121026153K

[12] Zevallos, W.T., Salvatierra, L.M. and Pérez, L.M. (2015) Evaluación de los mecanismos de eliminación de $\mathrm{Pb}^{2+}$ en sistemas de fitorremediación en lotes operados con Salvinia biloba raddi (acordeón de agua). Energeia, 13, 1668-1622.

http://bibliotecadigital.uca.edu.ar/repositorio/revistas/evaluacion-mecanismos-elim inacion-fitorremediacion.pdf

[13] Marmiroli, M., Antonioli, G., Maestri, E. and Marmiroli, N. (2005) Evidence of the Involvement of Plant Ligno-Cellulosic Structure in the Sequestration of $\mathrm{Pb}: \mathrm{An}$ X-Ray Spectroscopy-Based Analysis. Environmental Pollution, 134, 217-227. https://doi.org/10.1016/j.envpol.2004.08.004

[14] Kabata-Pendias, A. (2011) Trace Elements in Soils and Plants. CRC Press, 1-534. http://books.google.com/books?hl=en\&lr=\&id=Nowwb0xl9fYC\&oi=fnd\&pg=PA1\& $\mathrm{dq}=$ Trace+Elements+in+Soils+and+Plants\&ots=JHbMeb6awr\&sig=mgHuQeRhLlL YYzMwQS7C1NvVhQg

[15] Li, T.Q., Yang, X.E., Lu, L.L., Islam, E. and He, Z.N. (2009) Effects of Zinc and Cadmium Interactions on Root Morphology and Metal Translocation in a Hyperaccumulating Species under Hydroponic Conditions. Journal of Hazardous Materials, 169, 734-741. https://doi.org/10.1016/j.jhazmat.2009.04.004

[16] Twardowska, I. and Kyziol, J. (2003) Sorption of Metals onto Natural Organic Matter as a Function of Complexation and Adsorbent-Adsorbate Contact Mode. Environment International, 28, 783-791. https://doi.org/10.1016/S0160-4120(02)00106-X

[17] Fernandez Aguilar, L. and Enrique, P.S. (2013) Accumulating Capacity of Cadmium in Scirpus Californicus Roots Exposed to Different Concentrations of Cadmium Nitrate under Laboratory Conditions. Rebiolest, 1, 14-22. 
[18] Yang, J.X. and Ye, Z.H. (2009) Metal Accumulation and Tolerance in Wetland Plants. Frontiers of Biology in China, 4, 282-288.

https://doi.org/10.1007/s11515-009-0024-7 